\title{
The invisibility of the patient's family in nursing documentation: An integrative review
}

\author{
Heleena Laitinen*1, Eija Paavilainen ${ }^{2,3}$ \\ ${ }^{1}$ Tampere University of Applied Sciences, Tampere, Finland \\ ${ }^{2}$ Faculty of Social Sciences/Heath Sciences, University of Tampere, Tampere, Finland \\ ${ }^{3}$ South Ostrobothnia Hospital District, Seinäjoki, Finland
}

Received: April 2, 2017

DOI: $10.5430 /$ cns.v5n3p54
Accepted: July 4, 2017

URL: https://doi.org/10.5430/cns.v5n3p54

\begin{abstract}
Objective: The objective of this integrative review is to present the current state of research knowledge regarding references to the patient's family in documentation in health care settings.

Methods: Ten $(\mathrm{N}=10)$ research articles from 1998 to 2014 were found and analyzed using inductive, thematic analysis. All articles were evaluated using the critical appraisal tools developed by the Joanna Briggs Institute (JBI).

Results: Two main themes were revealed: the content and the structural aspects of family documentation. Quantitative, qualitative and mixed methods were used in generating the data of the reviewed articles. Reference to families in documentation was considered important in all the articles. Structural aspects consisted of semi-structured forms, summary notes and a tick-box system for marking the issues which were discussed with families. The classification system and outcomes assessment regarding family documentation were investigated, and their importance was highlighted. The content of family documentation was typified, for example, by parenting issues in mental health status and how the parents cope when a child is ill. Difficult life situations and advanced care planning brought families into the documentation, albeit rather infrequently. Similarly, references to counseling families or considering their psychosocial, spiritual and cultural dimensions were rarely found in the literature. Additionally, the family's importance in supporting the patient's care was often missed in documentation.

Conclusions: The results show the necessity of developing both family nursing and its documentation. Consequently, in order to improve the quality of both of these, more investigation from multiple perspectives is needed.
\end{abstract}

Key Words: Patient's family, Family nursing, Nursing documentation, Family documentation, Patient records, Integrative literature review

\section{INTRODUCTION}

The aim of family nursing is to help both patients and families maintain a supportive relationship in health care. ${ }^{[1,2]}$ The focus of family nursing is on both the patient's and the family members' concerns in various health/illness situations. ${ }^{[2,3]}$ It is also important to understand that family nursing includes the entirety of a person's lifespan, thus applying to patients from child care to elderly care in all health care settings. ${ }^{[3]}$
The important goal in all its phases is to promote the wellbeing of the whole family. ${ }^{[3]}$ In this integrative literature review, the focus is on revealing how the presence of the patient's family is documented in patient records.

The importance of collaboration between hospital staff and patients' family members has been studied widely. ${ }^{[4-7]}$ The bond between family members is fundamental. When patients are in hospital, they are still members of their fam-

*Correspondence: Heleena Laitinen; Email: heleena1 @elisanet.fi; Address: Vellamonkatu 22 A 21, 33500 Tampere, Finland. 
ily. Patients worry about their family members, and vice versa. ${ }^{[8]}$ Being separated from family members can lead to distress as well as physical and psychological disorders. ${ }^{[9]}$ The importance of family presence and visitation is also much appreciated in acute critical situations. ${ }^{[10,11]}$ Smith et al. ${ }^{[12]}$ indicated that open and flexible visiting times in intensive care units increased both patients' and family members' satisfaction, leading to positive changes for all the family. Moreover, it is important that adult patients themselves define their close family members ${ }^{[10]}$ and make the decisions regarding family members' participation in their care. ${ }^{[13]}$ Family members are often the patients' legal representatives and thus act as advocates for the patients in difficult health situations. ${ }^{[14]}$ Furthermore, both patients and family members need informational and emotional support in order to cope at home. ${ }^{[15]}$ In a study by Mattila et al., ${ }^{[15]}$ the nurses supported patients and families, e.g., by caring, giving information, and dealing with emotional situations. By having a supportive relationship with the nurses, the family members felt accepted and available to be involved with their close one's treatment. However, when the support was inadequate, the family members felt themselves "outsiders" regarding the treatment given their close ones. ${ }^{[15]}$ Sharing information with the family members gives them an understanding of how they can cope in the at-home collaboration. ${ }^{[16]}$ Nevertheless, according to Majasaari et al., ${ }^{[17]}$ the patient's family members seem to be quite invisible, e.g., in discharge counseling situations.

Genuine patient-focused documentation reveals the voice of the patients ${ }^{[18]}$ and, as an integral part of nursing, documentation has a crucial place from the family perspective as well. ${ }^{[8,18,19]}$ Browning ${ }^{[20]}$ stresses the importance of family documentation, which may be advanced by electronic records; documentation is a beneficial way to collect data from family members for interdisciplinary collaboration.

Documentation of relevant information in patient records is a legal responsibility worldwide. Writing patient records concerns all health care professionals. ${ }^{[21]}$ There are occasions in health care when authorized family members have to take responsibility for making decisions on behalf of the patients, e.g., because of the patient's health condition. In situations when patients cannot communicate, there are significant family issues which need to be documented. ${ }^{[10]}$ When family members take responsibility for the patient's care, the documented information is essential. ${ }^{[22]}$ For example, in the country of the present authors, Finland, the status of close relatives or legal representatives as patients' advocates is spelled out in the law. ${ }^{[23]}$

Current health systems are complex. ${ }^{[8,24]}$ In the totality of one care process, patients can be treated in numerous units with multiple health professionals participating. ${ }^{[24]}$ In such fragmented and complex situations, an effort needs to be made to involve family members in the patient care. ${ }^{[24]}$ To support the continuity, effective documentation is required $^{[8,25,26]}$ and it is a way to both communicate with the interdisciplinary professionals ${ }^{[20]}$ and promote the patients' safety. ${ }^{[27]}$

Patients themselves appreciate when nurses involve their family members in their care. ${ }^{[19,28]}$ It has been shown that it was often the patients' own initiative in establishing that their spouse could come to an admission meeting with a nurse or to a doctor's appointment. This was a way to have emotional and informational support. ${ }^{[8]}$ Family members' participation in the patient's life can be crucial in the time ahead, ${ }^{[2,7,29]}$ as they are the ones who primarily take care of the patients at home after discharge; hence, they need guidance and support from competent professionals. ${ }^{[11,28,29]}$ When patients and their family members live their lives outside of hospitals, but using health care services, the continuity of high-quality treatment can be ascertained by means of accurate documentation. ${ }^{[8]}$ Such documentation is also needed when family members are the permanent caregivers of their loved ones, in order to support all the parties in coping. ${ }^{[29-32]}$

In several previous studies concerning documentation, the importance of family members has been mentioned. ${ }^{[33-35]}$ Also, families' participation was documented in regard to coordinating the continuity of care. ${ }^{[18]}$ However, the actual participation of family members in the patient care is, in general, quite briefly noted in such documentation, even though it has a crucial relevance for the patient's discharge from hospital and survival at home. ${ }^{[36]}$ As part of their action research, Okaisu et al. ${ }^{[37]}$ included the family nursing perspective in the hospital admission process in order to improve the documentation. So, the importance of patients' family members has been noticed as participants in the treatment, but their visibility in documentation has remained on the level of mentioning.

Nursing documentation has been extensively studied and many literature reviews have promoted a vast body of knowledge from multiple viewpoints. ${ }^{[34,38-43]}$ However, the interest of the authors of this paper has been piqued by the apparent absence of any previous literature review specifically focusing on family documentation. Therefore, the aim of the authors here is to conduct an integrative literature review of the existing knowledge on this topic.

\section{Purpose of the study}

This integrative literature review aims to describe existing research knowledge regarding documentation which has been 
done concerning the family while one of them is a client or patient in some health care setting.

The research question is: What is known about family documentation in health care settings?

\section{MethodS}

This study is based on an integrative review method which includes problem identification, a literature search, data evaluation, data analysis and reporting the results. ${ }^{[4]}$ The integrative review method is very suitable for synthesizing data available in topics which have scarcely been studied, such as family documentation. Studies included in an integrative review can be done by different research methods and the results are presented in narrative form, often by thematic analysis. This approach facilitates the acquisition of a detailed general understanding of a research focus. This understanding can generate additional studies or development in the area. $^{[45]}$

\subsection{Database search and selection of articles}

Data searches were performed with assistance from an information specialist at the University of Tampere library. The search terms were carefully selected by the researchers and the information specialist and the searches were planned and conducted together in the databases Cinahl and Medline. The search terms are described in Figure 1. The terms were used in all possible combinations, for enhancing finding of all studies which answer our research question. A manual search was also conducted in reference lists of articles already selected for the review. Figure 1 describes the search, search terms and selection processes of the data for this study. Data search and selection were quite complex, due to the lack of studies concerning the topic, i.e., family documentation. Many studies first showed promising but after reading them, they were not about the topic of interest. Excluded articles did not meet the inclusion criteria and are not presented.

Data of the included articles were analyzed and described in Table 1. The table consists of the authors of the article, country, critical appraisal; aims; methods and participants of the study; and the results related to family documentation, reduced from the original studies selected in this integrative review. Data included only original articles or those which were part of a larger study but reported as an individual study. The articles were published in Japan $(\mathrm{n}=1)$, Canada $(n=2)$, Australia $(n=2)$, Sweden $(n=1)$, the USA $(n=2)$, Norway $(n=1)$ and the Netherlands $(n=1)$. Mixedmethod studies $(n=2)$ used both a quantitative and qualitative approach. The research data $(\mathrm{N}=10$ studies $)$ also include studies using only qualitative $(n=5)$ or quantitative $(n=3)$ approaches. Research concerning family documentation was done in the contexts of patient education, health promotion, chronic illness, palliative care and mental health, concerning both children and adults.

\subsection{Data evaluation}

All selected articles were critically appraised using the criteria presented by the Joanna Briggs Institute (JBI). Separate assessment criteria are outlined for qualitative, quantitative and mixed-method studies. ${ }^{[46]}$ Each assessment tool has up to 11 criteria statements which were then evaluated. The quality of articles was acceptable, varying from 4 to 10 points; the points of each study are described in more detail in Table 1. However, they were the best which were available for this little-studied topic.

\subsection{Data analysis}

Thematic analysis ${ }^{[47]}$ allows recognition of significant topics or prominent themes, as well as organized and structured ways of dealing with the content under these themes. It also allows integrating the data from qualitative and quantitative studies, while summarizing the results of different studies under thematic headings, based on the data. Thematic, inductive data analysis was conducted to reveal the themes among the review articles, based on the research question. In order to identify the themes, the chosen articles were read multiple times. ${ }^{[4,45,47,48]}$ Text segments answering the research question were first reduced in Table 1 and after that named and combined, according to their content. Two main themes were revealed, describing the content and structural aspects of the family documentation.

\section{RESULTS}

In general, documenting different aspects of families, besides the patient, was considered important in all papers included in this study. Two main themes are presented in the following.

\subsection{Structural aspects of family documentation}

Family care was considered as one central domain of documentation. ${ }^{[49]}$ Family relationships, describing key persons in patient care, are crucial. ${ }^{[50]}$ It is important that the documenting system requires who in the family should be included in the care of the patient. ${ }^{[51]}$

Nurses' notes, both in a semi-structured format and as summary notes, are essential for describing high-level familycentered work. ${ }^{[51]}$ Also, the use of tick boxes, while discussing important points of care with families, is essential. ${ }^{[52]}$ A classification system in documentation is needed for structuring the documented issues in a format which advances their use as the basis of care. Quality indicators ${ }^{[49]}$ and describing care outcomes concerning families ${ }^{[53]}$ are means for

ISSN 2324-7940 E-ISSN 2324-7959 
the assessment of care. Heimendigger's study ${ }^{[53]}$ contained various measures, thus the findings from the documentation were not directly within reach. However, the study gives a worthy pattern for the use of documentation, including a standardized methodology for how issues are discussed with a patient's family members and how they are documented.

Search terms in Cinahl \& Medline:

patient, family, family member, relative, next-of-kin, family nursing, family centered/oriented/focused care, family assessment, family care, family systems nursing, documentation, charting, medical records, computerized patient record, nursing records, patient record systems, electronic patient/health records; combined in different ways, with or/and $=850$

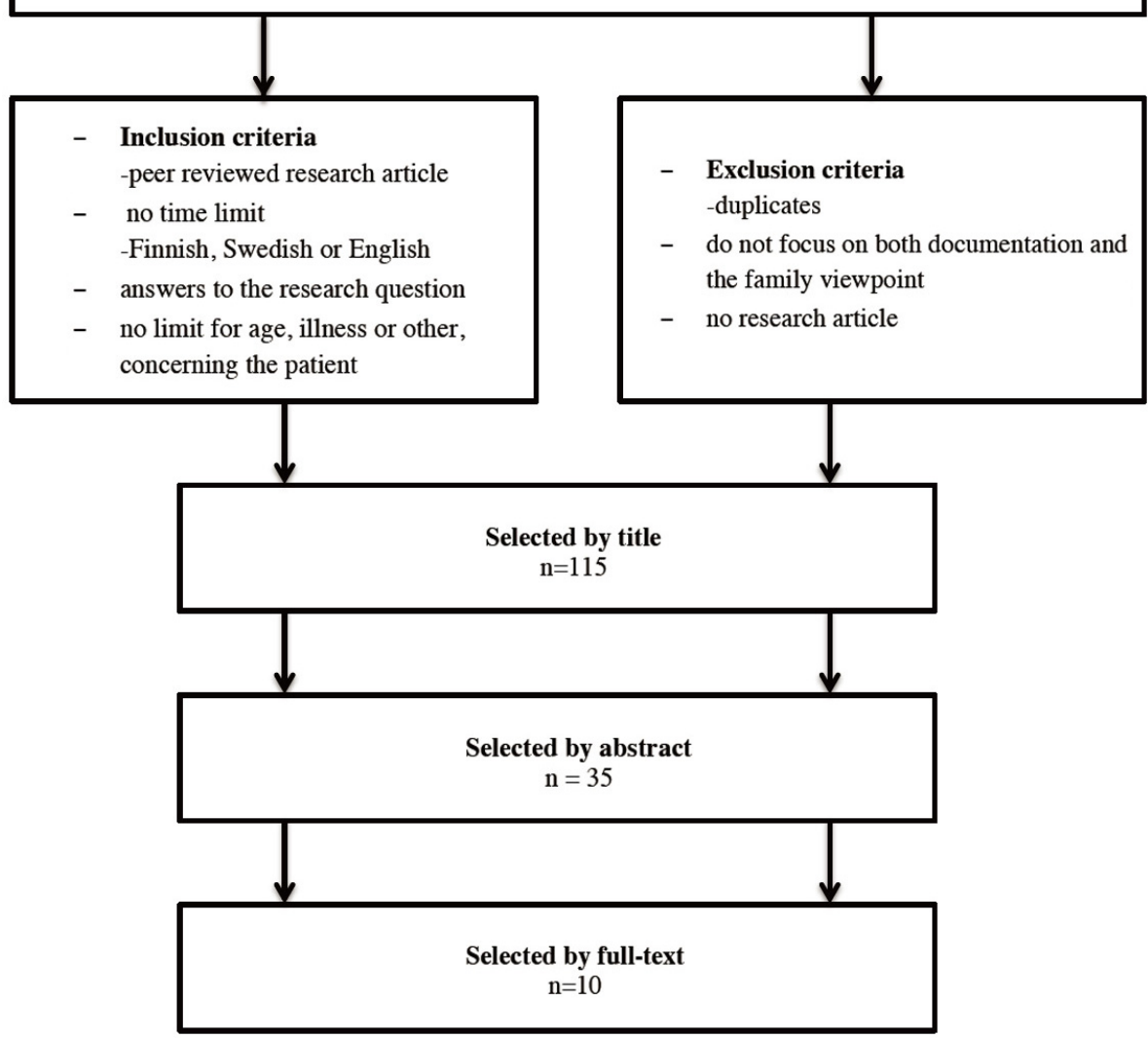

Figure 1. Database searches and data selection, by inclusion and exclusion

\subsection{Content of family documentation}

Parenting issues comprise an important aspect of the work of community mental health nurses, and there is a need to highlight the systematic identification of parental status in mental health patients. ${ }^{[54]}$ Documenting parenting issues is considered important, e.g., parents expressing difficulties in coping with their role in the context where their child is ill. ${ }^{[54]}$ Miyashita et al. ${ }^{[49]}$ found that expectations of the family in discussing crucial issues, e.g., about do-not-resuscitate, are very important to document. Similarly, Heyland et al. ${ }^{[55]}$ emphasized the importance of documenting advanced care planning for end-of-life care. However, even though patients and family members expressed preferences when asked about end-of-life care, in almost $30 \%$ of the included data their views were not documented. ${ }^{[55]}$
Family presence during counseling, ${ }^{[50]}$ family-focused nursing diagnoses ${ }^{[56]}$ and psychosocial, spiritual and cultural aspects of patient and family care ${ }^{[57]}$ were found to be important to document, however infrequently this is actually done. It was found that family members are a supportive resource in care; however, this is not as well documented as it should be. ${ }^{[56]}$ Heimendigger ${ }^{[53]}$ found it important to document family visits and coaching conversations with them. Family advisors documented the time, date, and location of the visit, as well as family member participation, personal involvement and family dynamics during those conversations. ${ }^{[53]}$

According to Rotegård, ${ }^{[58]}$ the family was mentioned in documentation from motivational and protective perspectives of how the patient felt about the family, and especially concerning (1) the patient's children, e.g., the wish to see them 
grow, and (2) the spouse, in regard to issues such as worry and exhaustion. Thus, it was an important aspect to describe the patients' feelings about their family members.

The involvement of families in documentation of the education provided at patient discharge was investigated by Cook et al. ${ }^{[50]}$ In the electronic medical records of patient education documented most often $(n=173)$, the frequency of patient and family together was 23 , while the frequency involving the family alone was quite low $(n=3)$.

This literature review showed discrepancies between nursing care and its documentation. Hegarty et al. ${ }^{[57]}$ noted that the families' concerns were part of the nursing care, but these concerns only rarely showed up in the documentation. According to Heyland et al., ${ }^{[5]}$ the preferences which patients and families expressed were not consistent with what was written in the documentation.

In the study by Ziegert, ${ }^{[56]}$ the revealed themes emphasized the family members' supportive resources, enabling their readiness to contribute to the patients' home care and to co-operate with them in that care.

\section{Discussion}

\subsection{Discussion of the results}

It is important to emphasize that the present authors' focus was especially on family nursing documentation. While, in general, patient documentation has been thoroughly investigated, curiously, family documentation ${ }^{[18]}$ has not. However, there are many studies ${ }^{[18,59]}$ which stress the need for family documentation and have contributed to the development of family documentation.

With the exception of the study by Ziegert et al., ${ }^{[56]}$ there were no other studies concentrating purely on family documentation. Documentation was used as a data collection method, among others, in several studies. Myashita et al. ${ }^{[49]}$ used medical charts to find quality indicators of cancer patients' end-of-life. Heimendinger et al. ${ }^{[53]}$ assessed the outcomes of a coaching program, with the purpose of promoting a healthy lifestyle among schoolchildren. Rotegård et al. ${ }^{[58]}$ investigated the health assets of cancer patients.

When a patient falls ill, the significance of the family is crucial. On the basis of the results revealed in the present study, the importance of family involvement in documentation should be strongly emphasized. However, the results of this integrative review, as well as of other previous studies, found that the families in fact seem to be invisible in the documentation. This was confirmed in the literature review performed by Saranto and Kinnunen. ${ }^{[34]}$ The family members' presence was often noted in documentation, at some level, but they were objectified. This is consistent with the 58 results of a study by Laitinen et al. ${ }^{[26]}$

Furthermore, Reeves et al. ${ }^{[60]}$ observed that even though family members are ordinarily present in the ICU, their dayto-day interactions with the interprofessional care team have not been explored or documented. Documenting central issues concerning the family, besides the patient, is crucial for teamwork enhancing high-quality care. It is important to understand that professional competence is not only knowledge and skills in a specialized clinical area. The competence needs to be shown in the skills of interaction or communication with the patients and interdisciplinary partners. ${ }^{[8]}$

Studies included in this review describe family documentation as part of the diverse information retrieval. Personal experience as well as beliefs, attitudes and mindset are reflected in the writing. ${ }^{[61,62]}$ There is an old saying "if it is not documented, it is not done". This may reflect the fact that some health care professionals are more task-oriented than patient- or family-oriented. If health care professionals and, even more, the organizational hierarchies are not accountable for their patients' and family members' well-being and related documentation in the first instance, then a huge amount of valuable information for the continuity of care is lacking. ${ }^{[8]}$ The complexity and fragmentation of health care are acknowledged in previous literature. ${ }^{[8,11]}$ Consequently, without serious concentration on family members' involvement in nursing documentation, the safety and quality of the care processes are diminished. By taking action towards both family nursing practice and related documentation, the continuity of care would be improved.

\subsection{Ethics and the reliability of the study}

The authors of this paper have followed the guidelines of research ethics. ${ }^{[63]}$ Since this is an integrative review, the focus has been on transparency in the study process. ${ }^{[4]}$ The two authors both conducted the literature review. The data search was carried out first in collaboration with an information specialist at the university library. A wide range of key words and search terms was used in various search engines. The authors decided to use only English language terms, after noticing that their native language, Finnish, did not give any results in regard to the research question. Also, a hand-search was performed, which yielded one more article. This can be considered as enhancing the reliability of the data search, since the total number of research papers about the topic remained small. All the stages of the review were conducted in agreed collaboration by both authors. This review is therefore limited to the surprisingly small number of studies pertaining to the review question. Significantly, of the included articles only one was purely focusing on family nursing documentation. ${ }^{[56]}$ However, this can be considered as a result, giving a wide-open field for further investigations. 
Table 1. The studies included in the integrative review

\begin{tabular}{|c|c|c|c|}
\hline $\begin{array}{l}\text { Author(s), year, country, } \\
\text { critical appraisal result }\end{array}$ & Aims & Methods and participants & Results describing family documentation \\
\hline $\begin{array}{l}\text { Ziegert K, et al. }{ }^{[56]} \\
2007, \text { Sweden } \\
8 / 10\end{array}$ & $\begin{array}{l}\text { To examine the professional support for } \\
\text { the next of kin (NoK) of chronic } \\
\text { haemodialysis patients, as documented } \\
\text { in the patient records. }\end{array}$ & $\begin{array}{l}\text { - Total of fifty }(\mathrm{N}=50) \text { patient records, each } \\
\text { approximately } 100 \text { pages. VIPS-model was the } \\
\text { organization of the records. } \\
\text { - Content analysis }\end{array}$ & $\begin{array}{l}\text { - family's role should be documented in family-focused } \\
\text { nursing diagnoses } \\
\text { - family members are a supportive resource in the nursing } \\
\text { care }\end{array}$ \\
\hline $\begin{array}{l}\text { Cook L, et al. }{ }^{[50]} \\
2008, \text { USA } \\
4 / 9\end{array}$ & $\begin{array}{l}\text { To assess the frequency and nature of } \\
\text { documentation of patient education by } \\
\text { interdisciplinary staff in electronic } \\
\text { medical records. }\end{array}$ & $\begin{array}{l}\text { - Review of electronic medical records of discharged } \\
\text { inpatients }(\mathrm{N}=244) \text {. } \\
\text { - Teaching intervention } \\
\text { - Quantitative analysis }\end{array}$ & $\begin{array}{l}\text { - most electronic patient records lack any patient education } \\
\text { - if documented, was done by nurses } \\
\text { - also some family presence during education was } \\
\text { documented } \\
\text { - the system requires who in the family should be included } \\
\text { in the educational process }\end{array}$ \\
\hline $\begin{array}{l}\text { Feeley N, et al }{ }^{[51]} \\
\text { 1998, Canada } \\
6 / 10\end{array}$ & $\begin{array}{l}\text { To describe the development of three } \\
\text { classification systems health concerns of } \\
\text { the families, strategies } \\
\text { to attain the goals and the observed } \\
\text { outcomes. }\end{array}$ & $\begin{array}{l}\text { - Intervention } \\
\text { - Recruited and consented families }(\mathrm{N}=332) \\
\text { randomly selected families with chronically ill } \\
\text { child, assigned to intervention group }(\mathrm{n}=171) \text { or } \\
\text { control group }(\mathrm{n}=161) \\
\text { - Content analysis }\end{array}$ & $\begin{array}{l}\text { - documentation should be done about the actions the } \\
\text { nurses take to help families achieve their goals } \\
\text { - nurses' notes (semi-structured format): description of the } \\
\text { family's current situation, the nurse's assessment, } \\
\text { strategies for intervention, any outcomes or changes } \\
\text { noted } \\
\text { - summary note: brief summary of the major features of the } \\
\text { work with each family }\end{array}$ \\
\hline $\begin{array}{l}\text { Hegarty M, et al. }{ }^{[57]} \\
2005 \text {, Australia } \\
9 / 10\end{array}$ & $\begin{array}{l}\text { To explore divergences between nurses' } \\
\text { knowledge and their documentation in } \\
\text { palliative care. }\end{array}$ & $\begin{array}{l}\text { - Retrospective case-notes of deceased patients } \\
(\mathrm{n}=20) \\
\text { - interviews of the nurses who were involved with } \\
\text { patients' care } \\
\text { - Qualitative interviews } \\
\text { - Quantitative audit }\end{array}$ & $\begin{array}{l}\text { - psychosocial, spiritual and cultural aspects of care are } \\
\text { infrequently documented }\end{array}$ \\
\hline $\begin{array}{l}\text { Heimendinger J, et al. }{ }^{[53]} \\
\text { 2007, USA } \\
7 / 10\end{array}$ & $\begin{array}{l}\text { To assess the outcomes of a coaching } \\
\text { programme, aiming to promote healthy } \\
\text { diets and physical activities among } \\
\text { school children. }\end{array}$ & $\begin{array}{l}\text { - Eighty-eight }(\mathrm{N}=88) \text { recruited families were } \\
\text { randomly chosen to an intervention group and a } \\
\text { 'delayed-control conditions'. } \\
\text { - Statistical analysis } \\
\text { - Qualitative interviews } \\
\text { - Chart review. }\end{array}$ & $\begin{array}{l}\text { - documenting the visits, coaching conversations } \\
\text { - family advisors documented time, date, location of the } \\
\text { visit, family member attendance, individual degree of } \\
\text { involvement, and family dynamics }\end{array}$ \\
\hline $\begin{array}{l}\text { Van Loo M, et al. }{ }^{[52]} \\
2008, \text { UK } \\
7 / 10\end{array}$ & $\begin{array}{l}\text { To assess the frequency of initiation and } \\
\text { non-initiation of discussion about tissue } \\
\text { donation with suddenly bereaved } \\
\text { relatives, by emergency nurses. }\end{array}$ & $\begin{array}{l}\text { - Patients' computerized case notes }(n=242) \\
\text { - Statistical analysis }\end{array}$ & $\begin{array}{l}\text { - nurses recorded notes on the computer, using a tick box } \\
\text { when they discussed tissue donation with the relatives } \\
\text { - the initiation episodes by individual nurses occurred } \\
\text { occasionally from one episode to eight; the non-initiation } \\
\text { episodes occurred from one to eighteen }\end{array}$ \\
\hline $\begin{array}{l}\text { Rotegård A, et al. }{ }^{[58]} \\
\text { 2012, Norway } \\
7 / 10\end{array}$ & $\begin{array}{l}\text { To describe health assets based on } \\
\text { analysis of nursing documentation in } \\
\text { cancer patients' records. }\end{array}$ & - Content analysis & $\begin{array}{l}\text { - family was mentioned in documentation regarding } \\
\text { relational, motivational, and protective perspectives } \\
\text { concerning how the patient felt about the family } \\
\text { - were connected with children (wish to see them grow, } \\
\text { says that they handle the illness well), and spouse (is } \\
\text { worried about her/him, sees that the spouse is exhausted) }\end{array}$ \\
\hline $\begin{array}{l}\text { Heyland DK, et al. }{ }^{[55]} \\
\text { 2013, Canada } \\
6 / 9\end{array}$ & $\begin{array}{l}\text { To determine the prevalence of an } \\
\text { advanced care plan and its components, } \\
\text { from the perspectives of acutely ill } \\
\text { patients and their family members, } \\
\text { To determine the concordance between } \\
\text { the patients' wishes and the care plan } \\
\text { documented in the medical record. } \\
\text { To assess the patients' and family } \\
\text { members' overall satisfaction with end } \\
\text { of life communication and decision } \\
\text { making during the last four weeks. }\end{array}$ & $\begin{array}{l}\text { - } 278 / 513 \text { patients }(54.2 \%) \\
\text { - } 225 / 366 \text { family members }(61.5 \%) \text { in } 12 \text { acute care } \\
\text { hospitals } \\
\text { - Interviews with patients and family members using } \\
\text { a questionnaire; } \\
\text { - The medical record review immediately after the } \\
\text { interview }\end{array}$ & $\begin{array}{l}\text { - less than a third of the patients and families were asked } \\
\text { about the advanced care plans (ACP) } \\
\text { - patients' preferences about end of life care were poorly } \\
\text { documented and there were discrepancies between the } \\
\text { preferences and their documentation; family members } \\
\text { have expressed preferences for medical treatments at the } \\
\text { EOL } \\
\text { - communication with health care professionals and } \\
\text { documentation of EOL care preferences is inadequate }\end{array}$ \\
\hline $\begin{array}{l}\text { Liangas G, et al. } .^{[54]} \\
2014 \text {, Australia } \\
6 / 10\end{array}$ & $\begin{array}{l}\text { To audit parental records about the } \\
\text { issues of parental concerns regarding } \\
\text { their children's mental health issues. }\end{array}$ & $\begin{array}{l}\text { - Audited files }(\mathrm{N}=280) \text {, } \\
\text { - } 175(\mathrm{n}=175) \text { with parental concerns training } \\
\text { intervention } \\
\text { - Quantitative analysis }\end{array}$ & $\begin{array}{l}\text { - parenting issues are a significant part of the work load for } \\
\text { mental health teams } \\
\text { - need to highlight systematic recognition of parental } \\
\text { status involving mental health patients } \\
\text { - parenting issues documented: parents expressing } \\
\text { difficulties in coping with parental role, parents rely on } \\
\text { children for support, parenting support, children's } \\
\text { welfare and safety, parenting issue mentioned as a } \\
\text { problem }\end{array}$ \\
\hline $\begin{array}{l}\text { Miyashita M, et al. }{ }^{[49]} \\
2008, \text { Japan } \\
9 / 10\end{array}$ & $\begin{array}{l}\text { To identify quality indicators (QI) of } \\
\text { end-of-life of cancer care by reviewing } \\
\text { medical charts. }\end{array}$ & $\begin{array}{l}\text { Modified Delphi method, based on systematic } \\
\text { literature review about QI using communication in } \\
\text { the internet; participants multi-professional } \\
\text { specialists }(\mathrm{n}=17) \text {; palliative care physicians } \\
(\mathrm{n}=5) \text {; medical oncologist }(\mathrm{n}=1) \text {; general } \\
\text { medicine physician }(\mathrm{n}=1) \text {; psycho-oncologists } \\
(\mathrm{n}=3) \text {; sociologists }(\mathrm{n}=2) \text {; medical ethicist } \\
(\mathrm{n}=1) \text {; expert on Delphi methodology }(\mathrm{n}=1)\end{array}$ & $\begin{array}{l}\text { - family care as one central domain of documentation: } \\
\text { family relationships, key person in patient care, family's } \\
\text { preference of place of care/explanation of medical } \\
\text { condition, explanation of medical condition to patient or } \\
\text { family, expectations of family, discussion about a } \\
\text { do-not-resuscitate order, explanation to family about: } \\
\text { course of disease until death, patient's impending death, } \\
\text { one week prior to death, care strategy for family }\end{array}$ \\
\hline
\end{tabular}




\section{Conclusions}

Documentation related to family nursing is quite scarce. This may partly demonstrate how health care staff feel about the family as a collaborative companion in patient care. On the other hand, it may also demonstrate deficiencies in documentation in general. This could be improved by means of basic and continuing education and by developing practices and working conditions which enable a family presence and involvement in patient care and, consequently, related documentation. With comprehensive documentation, involving the patients and their families, the quality and continuity of care can be improved. In addition, more research is needed in order to improve family documentation.

\section{ACKNOWLEDGements}

We are grateful to Mark Matson for revising the language of this paper.

\section{CONFliCtS OF INTEREST Disclosure}

The authors declare they have no conflict of interest.

\section{REFERENCES}

[1] Friedemann ML. The concept of family nursing. J Adv Nurs. 1989 Mar; 14 (3): 211-216. PMid: 2715522. https://doi.org/10.1 111/j.1365-2648.1989.tb01527.x

[2] Bell J. Relationships: The Heart of the Matter in Family Nursing. J Fam Nurs. 2011; 17(1): 3-10. https://doi .org/10.1177/1074 840711398464

[3] Åstedt-Kurki P. Family Nursing Research for Practice: The Finnish Perspective Journal of Family Nursing. J Fam Nurs. 2010; 16(3): 256-268. https://doi .org/10.1177/1074840710377204

[4] Chen HY, Boore JRP. Establishing a super-link system: spinal cord injury rehabilitation nursing. J Adv Nurs. 2007; 57(6): 639-648. https://doi.org/10.1111/j.1365-2648.2006.04160.x

[5] Salin S, Kaunonen M, Åstedt-Kurki P. Nurses' Perceptions of Their Relationships with Informal Carers in Institutional Respite Care for Older People. Nurs Res Pract. 2013; 9. https ://doi .org/10.115 $5 / 2013 / 967084$

[6] Paavilainen E, Salminen-Tuomaala M, Leikkola P. Counselling for patients and family members: A follow-up study in the emergency department. Int Sch Res Notices. 2014; 2012: 303790.

[7] Salminen-Tuomaala MH, Åstedt-Kurki P, Rekiaro M, et al. Coping With the Effects of Myocardial Infarction From the Viewpoint of Patients' Spouses. J Fam Nurs. 2013; 19(2): 198-229. https://doi.org/10.1177/1074840713483922

[8] Laitinen H. The Significance of Proximity and Timeliness for Patientfocused Nursing Care and Electronic Documentation in Acute Care Wards [dissertation]. Tampere, Finland: University of Tampere; 2014 $99 \mathrm{p}$.

[9] Karhe L, Kaunonen M. Patients' Experiences of Loneliness in a Professional Caring Relationship. Int. J. Hum. Caring. 2015; 19(1): 19-26. https://doi.org/10.20467/1091-5710-19.1.19

[10] Usher B. Family visitation in the adult intensive care unit. Crit Care Nurse. 2016; 36(1): e15-e19. https://doi.org/10.4037/ccn2 016677

[11] Guzzetta C. Family presence during resuscitation and invasive procedures. Crit Care Nurse. 2016; 36(1): e11-e14. https://doi.org/ $10.4037 / \operatorname{ccn} 2016980$

[12] Smith L, Medves J, Harrison MB, et al. The impact of hospital visiting hour policies on pediatric and adult patients and their visitors. Joanna Briggs Institute Library of Systematic Reviews. 2009; 7(2): 38-79. https://doi.org/10.11124/01938924-2009070 20-00001

[13] Paavilainen E, Seppänen S, Åstedt-Kurki P. Family involvement in perioperative nursing adult patients undergoing emergency surgery. J
Clin Nurs. 2001; 10(2): 230-237. https ://doi .org/10.1111/j 1365-2702.2001.00477.x

[14] Shield RR, Wetle T, Teno J, et al. Vigilant at the end of life: family advocacy in the nursing home. J Palliat Med. 2010; 13(5): 573-9. https://doi.org/10.1089/jpm.2009.0398

[15] Mattila E, Kaunonen M, Aalto P, et al. The method of nursing support in hospital and patients' and family members' experiences of the effectiveness of the support. Scan J Caring Sci. 2014; 28(2): 305-314. https://doi.org/10.1111/scs.12060

[16] Raitanen K, Kylmä J, Paavilainen E. Short-term patient and family counselling for acute health change - an integrative review. Clinical Nursing Studies. 2015; 3(3): 96-104. https ://doi .org/10.543 0/cns.v3n3p96

[17] Majasaari H, Paavilainen E, Åstedt-Kurki P. The visible and invisible family: Nurses' perceptions of counselling in day surgical nursing. J Adv Perioperat Care. 2007; 3(1): 11-19.

[18] Laitinen H, Kaunonen M, Åstedt-Kurki P. Patient-focused documentation expressed by the nurses. J Clin Nurs. 2010 Feb; 19(3-4): 489-497. https://doi.org/10.1111/j.1365-2702.2009.02983.x

[19] Mattila E. Aikuispotilaan ja perheenjäsenen emotionaalinen ja tiedollinen tuki sairaalahoidon aikana. [dissertation] (English abstract).Tampere, Finland; University of Tampere; 2010.

[20] Browning AM. Empowering Family Members in End-of-Life Care Decision Making in the Intensive Care Unit. Dimens Crit Care Nurs. 2009; 28(1): 18-23. https://doi.org/10.1097/01.DCC.00003 $25092.39154 .4 \mathrm{a}$

[21] Johnson M, Jefferies D, Langdon R. The Nursing and Midwifery Content Audit Tool (NMCAT): a short nursing documentation audit tool. J Nurs Manag. 2010; 18(7): 832-845.

[22] Kärkkäinen O, Eriksson K. Recording the content of the caring process. J Nurs Manag. 2005; 13(3): 202-208. https : //doi .org/10 $.1111 / \mathrm{j} .1365-2834.2005 .00540 . \mathrm{x}$

[23] Laki potilaan asemasta ja oikeuksista (1992/785). [Act on Patients' Rights and Status (1992/785)]. 1992. Available from: finlex.fi

[24] Wiggins MS. The partnership care delivery model: an examination of the core concept and the need for a new model of care. J Nurs Manag. 2008; 16(5): 629-638. https://doi.org/10.1111/j.13 $65-2834.2008 .00900 . x$

[25] Gjevdon ER, Helleso R. The quality of home care nurses' documentation in new electronic patient records. J Clin Nurs. 2010; 19(1-2): 1008. https://doi.org/10.1111/j.1365-2702.2009.02953.x

[26] Laitinen H, Kaunonen M, Åstedt-Kurki P. The impact of using mobile electronic patient records on practices of reading and writing. 
Health Informatics J. 2014; 20(4): 235-249. https : //doi . org/10 $.1177 / 1460458213492445$

[27] Owen K. Documentation in nursing practice. Nurs Stand. 2005; 19(32): 48-49. https://doi.org/10.7748/ns.19.32.48.s49

[28] Laitinen H, Kaunonen M, Astedt-Kurki P. When time matters: the reality of patient care in acute care settings. Int J Nurs Pract. 2011; 17(4): 388-395. https://doi.org/10.1111/j.1440-172X.20 $11.01945 . x$

[29] Lui MHL, Ross FM, Thompson DR. Supporting Family Caregivers in Stroke Care A Review of the Evidence for Problem Solving. Stroke. 2005; 36(11): 2514-2522. PMid: 16210553. https : //doi.org/10.1161/01.STR.0000185743.41231.85

[30] Nayeri ND, Mohammadi S, Razi SP, et al. Investigating the effects of a family-centered care program on stroke patients' adherence to their therapeutic regimens. Contemp Nurs. 2014; 47(1-2): 88-96. https://doi.org/10.1080/10376178.2014.11081910

[31] Salin S. Lyhytaikaisen laitoshoidon reaalimalli vanhuksen kotihoidon osana (English abstract) [dissertation].Tampere, Finland; University of Tampere; 2008.

[32] Tower M, Chapoyer W, Green Q, et al. Registered nurses' decisionmaking regarding documentation in patients' progress notes. J Clin Nurs. 2012; 21(19-20): 2917-2929. PMid: 22784185. https: //doi.org/10.1111/j.1365-2702.2012.04135.x

[33] Weis J, Zoffmann V, Egerod I. Improved nurse-parent communication in neonatal intensive care unit: evaluation and adjustment of an implementation strategy. J Clin Nurs. 2014; 23(23-24): 3478-3489. https://doi.org/10.1111/jocn. 12599

[34] Saranto K, Kinnunen UM. Evaluating nursing documentation - research designs and methods: systematic review. J Adv Nurs. 2009; 65(3): 464-476. https://doi.org/10.1111/j.1365-2648.20 $08.04914 . \mathrm{x}$

[35] Broderick MC, Coffey A. Person-centered care in nursing documentation. Int J Older People Nurs. 2013; 8(4): 309-318. https: //doi.org/10.1111/opn.12012

[36] Højskov IE, Glasdam S. Transformation of admission interview to documentation for nursing practice. Scan J Caring Sci. 2014; 28(3): 478-85. https://doi.org/10.1111/scs. 12071

[37] Okaisu EM, Kalikwani F, Wanyana G, et al. Improving the quality of nursing documentation: An action research project. Curationis. 2014 Dec; 38(1): 11. https://doi.org/10.4102/curationis .v37i1.1251

[38] Müller-Staub M, Lavin MA, Needham I, et al. Nursing diagnoses, interventions and outcomes - application and impact on nursing practice: systematic review. J Adv Nurs. 2006; 56(5): 514-531. https://doi.org/10.1111/j.1365-2648.2006.04012.x

[39] Häyrinen K, Saranto K, Nykänen P. Definition, structure, content, use and impacts of electronic health records: A review of the research literature. 2008. Int J Med Inform. 2008; 77(5): 219-304. https://doi.org/10.1016/j.ijmedinf.2007.09.001

[40] Jeffries D, Johnson M, Griffiths R. A meta-study of the essentials of quality nursing documentation. Int J Nurs Pract. 2010; 16(2): 112-124. https://doi.org/10.1111/j.1440-172X.2009.018 $15 . \mathrm{x}$

[41] Paans W, Sermeus W, Roos MB, et al. Prevalence of accurate nursing documentation in patient records. J Adv Nurs. 2010; 66(11): 24812489. https://doi.org/10.1111/j.1365-2648.2010.05433 . $\mathrm{x}$

[42] Kelley TF, Brandon DH, Sharron L, et al. Electronic Nursing Documentation as a Strategy to Improve Quality of Patient Care. J Nurs Scholarsh. 2011; 43(2): 154-162. https : //doi.org/10.1111/j. $1547-5069.2011 .01397 . \mathrm{x}$

Published by Sciedu Press
[43] Wang N, Hailey D, Yu P. Quality of nursing documentation and approaches to its evaluation: a mixed-method systematic review. J Adv Nurs. 2011; 67(9): 1858-1875. https ://doi.org/10.1111/ j.1365-2648.2011.05634.x

[44] Whittemore R, Knafl K. The integrative review: updated methodology. J Adv Nurs. 2005; 52(5): 546-553. https://doi .org/10.1 $111 / j .1365-2648.2005 .03621 . x$

[45] Polit DF, Beck CT. Nursing Research. Generating and Assessing Evidence for Nursing Practice. Eighth Edition. Philadelphia: Wolters Kluwer; 2012.

[46] The Joanna Briggs Institute. Joanna Briggs Institute Reviewers' Manual 2014. Available from: http://joannabriggs.org/assets/ docs/sumari/reviewersmanual-2014.pdf

[47] Dixon-Woods M, Agarwal S, Jones D, et al. Synthesising qualitative and quantitative evidence: a review of possible methods. J Health Serv Res Policy. 2005; 10(1): 45-53. https://doi.org/10.117 7/135581960501000110

[48] Aveyard H. Doing a Literature Review in Health and Social Care. A Practical Guide. Third Edition. McGraw-Hill Education. Glasgow: Open University Press; 2014.

[49] Miyashita M, Nakamura A, Morita T, et al. Identification of quality indicators of end-of-life cancer care from medical chart review using a modified Delphi method in Japan. American Journal of Hospice \& Palliative Medicine. Am J Hosp Palliat Med. 2008; 25(1): 33-38. https://doi.org/10.1177/1049909107307376

[50] Cook L, Castrogiovanni A, David D, et al. Patient education documentation: is it being done? Medsurg Nurs. 2008; 17(5): 306-310. PMid: 19051976.

[51] Feeley N, Gottlieb LN. Classification systems for health concerns, nursing strategies, and client outcomes: nursing practice with families who have a child with a chronic illness. Can J Nurs Res. 1998; 30(1): 45-59. PMid: 9726182.

[52] Van Loo M, Rabbetts C, Scott T. Emergency nurse initiation of discussion about tissue donation with suddenly bereaved relatives. Int Emerg Nurs. 2008; 16(4): 257-65. https://doi.org/10.1016/ j.ienj.2008.07.002

[53] Heimendinger J, Uyeki T, Andhara A, et al. Coaching process outcomes of a family visit nutrition and physical activity intervention. Health Educ Behav. 2007; 34(1): 71-89. https ://doi .org/10.1 $177 / 1090198105285620$

[54] Liangas G, Falkov A. Use of Structured Clinical Documentation to Identify Patients' Parental Concerns and Their Childrens' Wellbeing. Community Ment Health J. 2014; 50(6): 646-655. https: //doi.org/10.1007/s10597-013-9684-5

[55] Heyland DK, Barwich D, Pichora D, et al. Failure to Engage Hospitalized Elderly Patients and Their Families in Advance Care Planning. JAMA Intern Med. 2013; 173(9): 778-787. https ://doi.org/10 $.1001 /$ jamainternmed. 2013.180

[56] Ziegert K. Professional support for next of kin of patients receiving chronic haemodialysis treatment: a content analysis study of nursing documentation. J Clin Nurs. 2007; 16(2): 353-61. https: //doi.org/10.1111/j.1365-2702.2006.01597.x

[57] Hegarty M, Hammond L, Parish K, et al. Nursing documentation: non-physical dimensions of end-of-life care in acute wards. Int $\mathrm{J}$ Palliat Nurs. 2005; 11(12): 632-636. https://doi.org/10.129 68/ijpn.2005.11.12.20230

[58] Rotegård AK, Fagermoen MS, Ruland CM. Health Assets in Nursing Documentation of Cancer Care. Nurs Infor. 2012; 2012: 351.

[59] Papenfus H, Bryan AA. Nurses' Involvement in Interdisciplinary Team Evaluations: Incorporating the Family Perspective into Child Assessment. J. Sch. Health. 1998; 68(5): 184-189. https://doi . org $/ 10.1111 / j .1746-1561.1998 . t b 01298 . x$ 
[60] Reeves S, McMillan SE, Kachan N, et al. Interprofessional collaboration and family member involvement in intensive care units: emerging themes from a multi-sited ethnography. J Interprof Care. 2015; 29(3): 230-237. https://doi.org/10.3109/13561820.2 014.955914

[61] Helles $\emptyset$ R. Information handling in the nursing discharge note. J Clin Nurs. 2006; 15(1): 11-21. PMid: 16390519. https ://doi.org/10 $.1111 / \mathrm{j} .1365-2702.2005 .01235 . \mathrm{x}$

[62] Kärkkäinen O, Eriksson K. Structuring the documentation of nursing care on the basis of a theoretical process model. Scand J Caring Sci. 2004; 18(2): 229-236. https ://doi.org/10.1111/j .1471-671 $2.2004 .00274 . \mathrm{x}$

[63] TENK, Tutkimuseettinen neuvottelukunta. [The Finnish Advisory Board on Research Integrity]. Hyvä tieteellinen käytäntö ja sen loukkausepäilyjen käsitteleminen Suomessa. [Responsible Conduct of research and procedures for handling allegations of misconduct in Finland]. 2012. Available from: http://www.tenk.fi/sites/te nk.fi/files7HTK_ohje_2012.pdf 